\title{
Literary criticism from a Cape Town pulpit: Ramsden Balmforth's explications of modern novels as parables revealing ethical and spiritual principles
}

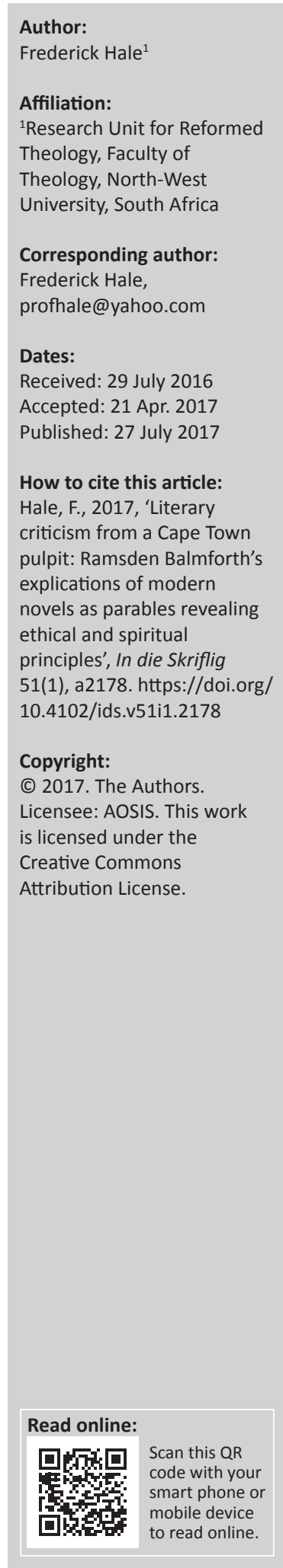

\begin{abstract}
Literary criticism evolved slowly in southern Africa. One of the first commentators to write about this topic was the Unitarian minister, Ramsden Balmforth (1861-1941), a native of Yorkshire and Unitarian minister who emigrated to Cape Town in 1897. Eschewing conventional homiletics in its various forms, in dozens of instances he illustrated ethical and spiritual points in his Sunday sermons or 'discourses' by discussing their manifestation in literary works. Crucially, these texts did not merely yield illustrations of Biblical themes, but themselves served as the primary written vehicles of moral and ethical principles, and the Bible was rarely mentioned in them. Balmforth's orations about novels were published in 1912. The following year he preached about selected operas by Richard Wagner, and in the 1920s Balmforth issued two additional series of discourses focusing on dramas. In all of these commentaries he consistently emphasised thematic content rather than narrative and other literary techniques. He extracted lessons which he related to his ethically orientated version of post-orthodox religious faith.
\end{abstract}

\section{Introduction}

The phenomenon of preaching has hardly been an unexplored topic in the history of Christianity. Its critical analysis boasts a long but inconsistent pedigree. Scholarly research has illuminated the homiletical approaches of many preachers while leaving those of most others in the shadows.

To cite but a handful of prominent examples, one can point to studies of preaching of such renowned British and American clergymen as James S. Stewart (Barbour 2000), Martin Luther King Jr. (Lischer 1997), Harry Emerson Fosdick (Ryan 1989), Fulton Sheen (Sherwood 2010) and Peter Marshall (Hyde 1963).

Meanwhile, the historical study of preaching in South Africa has advanced on an uneven front. Much of it has concentrated on a relatively small number of well-known divines such as Andrew Murray and others in the Dutch Reformed denominations. One of the many overlooked dimensions of this sub-topic is how Ramsden Balmforth, who served as the sagacious minister of the Free Protestant or Unitarian church in Cape Town from 1897 until 1937, perennially used various genres of modern literature in a series of sermons to impart his liberal understanding of Christianity to his cultivated and largely, though by no means exclusively, white audiences in Hout Street, whose ethnic composition was said to have been relatively diverse (Phillips 1927). Scholarly neglect of his preaching, which was frequently reported in the Cape Times and The Cape Argus, is unsurprising, given the diminutive size of his church which was nearly the sole Unitarian one in the country. For that matter, much of the general history of Unitarianism in South Africa remains unwritten, although the present writer has described the origins of the Free Protestant Church, which David P. Faure gathered in the 1860s and eventually evolved into a Unitarian congregation (Hale 2007).

Nevertheless, this major dimension of Balmforth's preaching merits scholarly attention for at least two significant reasons. First, at least within the South African context, he was apparently a pioneer in this kind of homiletics. His contributions to it, dealing not only with novels but also conventional dramas and even opera, were published in several books in London (Balmforth 1912; 1913; 1925; 1928). Second, despite the tiny size of his denomination, Balmforth was one of the most prominent churchmen and intellectuals in Cape Town. His influence extended far beyond earshot of his pulpit. In addition to his ministry in Hout Street (the core of which was his preaching on Sunday evenings), he wrote more than a dozen books about theological and literary 
topics and contributed articles to the daily and religious press as well as scholarly journals in South Africa, the United Kingdom and the United States of America. In his publications, he made noteworthy contributions especially in the fields of Biblical ${ }^{1}$ studies, Christian social ethics and literary criticism. Moreover, as a civic-minded soul in Cape Town, as he had been in his native Huddersfield, Balmforth served on various civic committees and played an active part in organisations such as the South African Peace and Arbitration Society and the Cape Fabian Society. For his efforts to promote social and educational reforms, he gained considerable recognition in his second homeland as well as in the country of his birth. Editor John Cope of the liberal Johannesburg weekly review The Forum assured readers, arguably too optimistically, in 1942 that 'Ramsden Balmforth will long be remembered in Cape Town and, indeed, in South Africa, as a pioneer of progressive thought' (Cope 1942:5).

Preachers have long mined literary works for sermon illustrations and by following in his predecessors' footsteps Balmforth was not entirely breaking new ground. However, the series under present consideration was noteworthy, because Balmforth's use of modern imaginative literature was not primarily a matter of referring to it in his explications of Biblical texts. Rather, in each of these discourses the primary emphasis was on the particular novel itself as a vehicle of some religious or ethical lesson or 'law' which Balmforth sought to impart. Balmforth (1932) believed that, generally speaking, the major religions of the world were finally recognising that 'human life is under the sway of spiritual laws which man must learn to obey'. In the present article steps will be taken towards redressing the neglect of this topic by examining a sample of Balmforth's sermons ${ }^{2}$ which were in fact commentaries on ethical and religious themes in works of English, American and French fiction. It will be shown that Balmforth highlighted what he perceived as the underlying ideas and 'laws' in those novels to express points which he wished to convey as central to his postorthodox Unitarian and Fabian socialist religio-political faith.

\section{Balmforth's political and religious background}

Balmforth's public explorations of literature cannot be well understood without some comprehension of his background in England, especially his involvement in Victorian religious and politico-economic life. Born in the Yorkshire industrial city of Huddersfield in 1861, this mechanic's son was not involved in organised religious life as a child or adolescent; instead, he and his siblings were received part of their education in schools sponsored by the Secular Society. Not until he was in his twenties did Balmforth begin to have

1.The use of 'Biblical' instead of 'biblical' is the author's preference.

2.In the present article, the term sermon is used inclusively to denote what Balmforth generally chose to call 'discourses'. His term was apt. For the most part, Balmforth's orations from the pulpit had little in common with what in Trinitarian churches are orations from the pulpit had little in common with what in Trinitarian churches are typically regarded as sermons, that is, explications of Biblical texts. However, one could argue that his discourses were intimately related to what is frequently called 'topical preaching', in which the sermon is typically and primarily a discussion of theme, often taken from everyday contemporary life, and based on Scriptural texts which are deemed to be related thereto. A crucial difference is that, for Balmforth the novels became the vehicles of truth - not merely latter-day illustrations of Biblical truth sympathy for any kind of Christianity. The documentation of his metanoia is meagre. At some early point, which in the 1930s Balmforth recalled obliquely, during his 'youth' (and therefore possibly in the late 1870s or early 1880s) he read Ernest Renan's Vie de Jésus (which had been translated into English as The life of Jesus almost immediately after its publication in French in 1863). He was sufficiently impressed by the post-orthodox portrayal of the Nazarene, which highlighted his ethical emphases, to deliver as one of his first lectures at an undisclosed venue 'A defence of Jesus' (Balmforth 1935:5-6). By the early 1890s Balmforth was affiliated with the Unitarian congregation in Huddersfield as whose minister he served briefly, following studies at Manchester College in Oxford. In the meantime, he had joined the Fabian Society in 1890 (Donnelly 2012). He remained an evolutionary, non-Marxist socialist for the rest of his life. His publications about social, political and economic issues in South Africa reflected his progressive, non-revolutionary views. Owing to his frail health, Balmforth answered a call to succeed Faure in the pulpit of the Free Protestant Church and emigrated to Cape Town when he was 36 years old. Apart from infrequent return visits to England and at least one trip to South Asia, he remained in that city until his death more than four decades later. Despite his very active participation in the religious, educational, political and cultural life of South Africa, he never severed his umbilical cord to British intellectual and cultural life. When one reads his many books and other publications, one can hardly fail to notice the on-going influence of the liberal theology he had imbibed in the late Victorian period. Overcoming early secularist antipathy to religion generally, Balmforth came under the sway of Unitarianism in his twenties, and at no subsequent point does he appear to have seriously questioned that tradition's modernist emphases.

At no time were Balmforth's theological views even in the vicinity of conventional, Trinitarian Protestantism. On the contrary, by his own account he was raised in a nonreligious family. Atheism had become a fairly visible public phenomenon in England by the mid-Victorian period, not least in working-class areas of industrial cities (Berman 1990). Writing late in life, the future Unitarian minister recalled that, unlike many church-going children in Huddersfield, he and his siblings attended a Sunday school sponsored by the National Secular Society (NSS) - a young and vibrant organisation. It was founded in 1866 chiefly by the increasingly prominent Victorian atheist, Charles Bradlaugh (Niblett 2011), and associates such as George Holyoake and Charles Watts in 1866 as an amalgamation of existing but considerably smaller bodies in the United Kingdom (Royle 1974; 1980). By the end of the 1880s, however, Balmforth had become involved in the local Unitarian church in Huddersfield and left behind the aggressive atheism of the NSS. He would eventually study for the Unitarian ministry at Manchester College in Oxford in the mid-1890s and briefly shepherd the denomination's flock in Huddersfield before sailing to Cape Town in 1897. 
Like his politics, Balmforth's religious views proceeded from evolutionary premises; there was very little space in his thought for timeless creedal formulations. Instead, certain principles, chiefly ethical, were universal and could be expressed in different religions in various ways. Within the Christian or Judaeo-Christian tradition, he also perceived progressive development in history. Ancient Judaism, in Balmforth's view, was essentially a tribal religious system whose deity (or deities) served the interests of the tribe - not those of humanity in general. This religion had gradually evolved during many centuries of early Hebrew history - an interpretation Balmforth (1904) had taken from the liberal Dutch Old Testament scholar Abraham Kuenen. It reached its zenith in the brotherhood of mankind ethics proclaimed by Jesus of Nazareth. Beginning with Paul, however, it had become partially frozen in a dogmatic system (Balmforth described it derisively as 'after-growth') which, in the following centuries, continued to calcify into doctrinal formulas to which the essentially ethical core took a back seat. In one of his discourses about the New Testament in 1905, he gave a catalogue of elements of contemporary Jewish thought. He believed that it had adversely influenced Paul's religious thought, including expectations of a 'Messianic Kingdom' and belief in the general resurrection of the dead, demons and evil spirits along with the idea of a supersensible world of spiritual beings - "angels, principalities, and powers"' (Balmforth 1905:129). The blessing of Protestantism, at least in its very liberal forms, Balmforth believed, was that it had recaptured much of the essential religion of Jesus. Moreover, in the 19th century, with the assistance of modern Biblical scholarship, that corner of Christianity with which Balmforth was most familiar had shed part of its outdated doctrinal baggage. In his own time it was steadily advancing on a liberal front. So convinced was Balmforth about this that, within a year of his arrival in Cape Town, he delivered a series of speeches about the progressive nature of the Christian religion in modern times and published it in London under the title The evolution of Christianity (Balmforth 1898).

In tandem with this underlying attitude, Balmforth did not believe that Christianity (or, of course, any other religion) was an exclusive channel or guardian of religious and ethical truth. In this regard, he appears to have been strongly influenced by the legacy of the eminent Oxford comparative religions scholar, Professor Max Müller, who had taught at the university from the early 1850s until well into the 1870s. Müller was still present there in active retirement when Balmforth began his studies at Manchester College. Indeed, one of his tutors at that institution, the Unitarian theologian Joseph Estlin Carpenter, was in the process of shifting his emphasis from Biblical studies to comparative religion (Farnell 1929). Going a step further, Balmforth did not believe that the sacred texts of religion generally were better vehicles of divine truth or 'laws' than, for example, dramas or novels. For that matter, he believed that what he deemed to be the 'best' of such un-canonical works, were superior in this regard in that they were more effective in the 20th century.
Balmforth was also a devotee of Darwinian evolutionary theory and believed that it went far to explaining not only the transformation of animal and plant species, but also the course of history, especially that of Western civilisation, which he interpreted as a the story of general if inconsistent progress towards greater human freedom and improvement. Writing in the South African Journal of Science in 1911, for example, he referred to the 'almost universal acceptance of the Darwinian theory of evolution'. He (Balmforth 1911) elaborated:

We think and speak in terms of evolution, and the theory has so far permeated all our thinking, that not only biological science, but ethics, economics, social and political theories and institutions are beginning to feel the influence of the new ideals and methods of thought which the theory has brought with it. (p. 386)

Accordingly, Balmforth believed that human conduct, especially in society, was governed by certain laws and that people lived most ethically and harmoniously when they obeyed them. This, too, influenced his reading of and preaching about fiction. He perceived many novelists emphasising the need for such adherence and calling the attention of readers to the dire consequences of failure to do so.

\section{An optimistic view of the spiritual power of literature}

Before turning to Balmforth's attitude towards fiction and its purposeful value to religious faith, we must remember that he was born and grew up in an era of rapidly expanding literacy when the number of novels published in the United Kingdom soared almost exponentially. He even contributed one to the seemingly endless list of Victorian fictional works, an absolutely didactic socialist piece written pseudonymously by 'Laon Ramsey'. It was little more than a dialogue between a young socialist and an Anglican clergyman of conservative bent in which the latter predictably comes second best. Mercifully, Balmforth abandoned his efforts to create novels after this initial, unreadable work, and his prose style improved rapidly in the 1890s and after the turn of the century. His conviction that fiction could serve as an effective means of conveying truth and changing minds remained intact, however, and underlay a goodly portion of his ministry in Cape Town.

The archival and other evidence of Balmforth's ministry in Cape Town does not allow us to ascertain when he began to use literary texts as the foundations of sermons. At any rate, by 1912 he was doing so with enough confidence to warrant publication of a compilation of his 'discourses' about novels. Issued in London that year, The ethical and religious value of the novel (Balmforth 2012) is a treasure trove of insights into his mind and that mode of explaining religious and ethical principles to an erudite audience comprising native speakers of both English and Afrikaans. In prefatory remarks, Balmforth revealed his understanding that there was little distance between the sacred and the secular, and 
that revelation of Truth was by no means channelled exclusively through religious texts. The purpose of his discourses was to show:

that ethical and religious teaching concerning such grave questions as Sin, Heredity, Will, Atonement, and the spiritual destiny of man should be universal in its scope, and that it should not be confined, in its illustrations and subject-matter, to the experiences of the Jews and the early Christians, or, in other words, to Biblical literature. (Balmforth 1912:v-vi)

Far from being limited to the ancient world of the Bible, these and other questions confront us daily, Balmforth reminded his flock, for 'the relations of man to the Infinite, are much the same for every age', and people who express answers to the ethical and religious questions arise in every generation: 'The call which came to Isaiah, to Jeremiah, and to Jesus, comes also to the thoughtful modern mind, differing only in form, in circumstance, in strength and insistency.' Accordingly, they recurred in texts of much more recent date: 'They may be illustrated from the best literature of every age, but especially from literature which brings us into close contact with the conditions of modern thought and life.' In this regard, he called novels 'parables' that illustrate truths no less vividly than those in which Jesus had taught nearly 1900 years ago (Balmforth 1912:v-vi).

Balmforth was aware that much literature did not even approach the standard he set for evaluating its quality. Generalising broadly, he (Balmforth 1912) laid bare his fundamental criterion for judging the value of any novel:

Does it make us better, stronger, for having read it? Does it make us think more? Does it enlarge and deepen our sympathies? Does it make us more deeply indignant and impatient with injustice? Does it cause us to modify or suspend judgment where we have been too ready to condemn? If it does these things it serves its purpose as well as or perhaps better than the most eloquent sermon, because it has a more lasting influence. (pp. x-xi)

To anyone who is familiar with the history of English literary criticism in the late 19th and early 20th century, Balmforth's views of the ethical function of fiction might seem familiar. It overlapped with what the ground-breaking Cambridge literary critic Frank Leavis would subsequently emphasise as the principal moral quality of literary works as the criterion for evaluating their value.

Therefore, to this socialist Unitarian in Cape Town, who espoused women's and non-racial suffrage, temperance, a removal of the 'colour bar' from the labour market and other reforms, fiction and the proclamation of the Gospel (at least in his post-orthodox, ethically orientated view of the latter) were potentially two sides of the same coin:

The aim of the preacher, fundamentally, is the same as that of the great novelist, the poet, and the philosopher - to give us deeper insight, and, with deeper insight, greater courage, and strength of will, and more abundant life. (Balmforth 2012:xii-xiii)

After a decade and a half in the pulpit this minister conceded that novelists could be more effective than practitioners of his own profession in conveying their message. 'Why, then, is the influence of the preacher waning while the influence of the novelist is increasing?' Balmforth asked prefatorily. One pivotal reason, he (Balmforth 2012) believed was that there:

cannot be the least doubt that the average preacher and the average sermon are often hopelessly out of touch with the realities of life. To listen to them must frequently be a weariness both to the spirit and to the flesh. To read them is impossible. They deal, not with a Kingdom of Life and God, but with a Kingdom of dead and dying things. (pp. xii-xiii)

\section{The supreme moral law in Adam Bede}

Because Balmforth regarded religion as, above all, a nurturing of ethical behaviour, it was particularly fitting that he began his 1912 series (at least as represented in the sequence of chapters in the published version of his discourses) with a consideration of George Eliot's début novel of 1859, Adam $B e d e$, as a parable of what he termed 'the supreme moral law'. He acknowledged that the 'intellectual attitude' of this prominent Victorian writer was 'purely agnostic', but her lack of theistic conviction did not deter him from declaring that she had 'created some of the most beautifully spiritual natures to be met with in the range of modern fiction'. Not only did her development of characters impress him. He found in all of Eliot's novels 'the slow, sure workings of an invisible spiritual law in and with which our lives are bound up'. No other Victorian, Balmforth believed, with the possible exception of George Meredith, 'depicts with so masterly a hand the deeper forces, motives, and instincts which rule our human life and destiny'. He found in Adam Bede a nearly perfect illustration of the 'spiritual forces' (which he declared were known by a variety of names, including 'The Eternal, not ourselves', 'The Absolute', and 'God') which rule our lives and 'cannot be ignored or explained away'. With this statement, Balmforth revealed his belief, which comes to the fore through various means in other publications, that the divine is not the transcendent deity of the Bible, but rather could be conceptualised as being to a great degree, the 'moral and spiritual forces which move the human soul in its struggle with itself and Destiny' (Balmforth 1912:21-23).

Establishing a pattern of first familiarising his audience with the novel under consideration, Balmforth outlined the plot before dissecting its themes and highlighting how, in this case, 'the Supreme Moral Law' was illustrated. Rather than focusing on the eponymous Bede, Balmforth highlighted the moral development of his rival Arthur Donnithorne to exemplify the gradual unfolding of character. This squire's son and army officer, he told his congregation, was never a particularly bad soul. Indeed, he could be 'kind, generous, impetuous, warm-blooded'. However, Arthur subordinated whatever ethical principles he had to his sex drive and he consequently seduced (and, unbeknown to him until much later impregnated) in an uncommitted, brief relationship a young village beauty, Hetty, with whom the village carpenter, Adam Bede, was sorely in love. Upon learning that after marrying Adam, she inadvertently caused the death of her 
(and Arthur's) infant and is therefore under indictment for murder, he races to save her and manages to get her death sentence commuted to permanent transportation. Her case, coupled with his realisation of his libidinous part in bringing about this tragedy, compelled him to understand that 'his careless, selfish gratification of light inclinations had brought a fellow-creature, a young girl who had trusted him, near to death, and to life-long imprisonment and ruin'. This, to the Unitarian parson, illustrated lucidly the Supreme Moral Law' that 'every thought we think and every deed we do affects for good or evil, not only our own life-if affects, through ourselves, through our radiating personality, innumerable lives' . Without referring explicitly to Matthew 7:12, Balmforth suggested to his flock that Adam Bede was essentially a parable illustrating the Golden Rule: 'To do unto others as we would have others do unto us were we in their place means that - it is only another way of expressing the Supreme Moral Law' (Balmforth 1912:32-33).

Balmforth understood the value of illustrations to concretise abstract ethical principles. Adam Bede, he declared to his flock, along with Eliot's other novels, could play a galvanising role in their lives, 'we not only feel better, we think better, we see more clearly, for having read them'. Such fictional reconstructions of life make it impossible for us to disregard 'the great truth that there is a reign of Law in the moral as well as in the physical world, and that this Law can never be broken with impunity'. Taking his hopeful view of humanity a step further, Balmforth believed that such reading and reflection of such modern parables 'helps the purification of our feelings and the guidance of our moral life'. In a flourish of optimism to which the Great War laid the axe to many a religious liberal's generous concept of human nature only a few years later, he assured his flock that Eliot's message regarding the possibility of human betterment could uplift the soul to glorious heights: 'Purified by its experience, and transformed by its longings and aspirations, it is slowly educated into deeper conceptions of what life really means' (Balmforth 1912:38-39).

\section{The law of retribution in The Scarlet Letter}

Balmforth followed this Victorian example with a discourse about a powerful novel from across the Atlantic, namely Nathaniel Hawthorne's The Scarlet Letter. Widely regarded as one of the greatest works of American fiction, this novel of 1850 powerfully portrays the fatal burden of guilt for unprocessed sexual sin, using a fictitious case set in Puritan New England. Balmforth recounted its plot to his congregation, concentrating on how Hester Prynne, a young Englishwoman in the 17th century, had been forced into a loveless marriage with a man far too much her senior. She emigrates to Boston and there uneagerly awaits her elderly husband's arrival. After a de facto separation of nearly two lonely years, she falls in love with a neophyte minister of the Gospel, Arthur Dimmesdale, who impregnates her - a crucial detail which Balmforth apparently thought too delicate to mention explicitly. Their child, a girl named Pearl, is born to this adulteress. The community punishes her with imprisonment and shame as she is required to wear a scarlet ' $A$ ' on her breast. That the parson is the father remains a secret. Dimmesdale is wracked by guilt and believes that she can relieve his crushing emotional burden by exposing him as Pearl's father, but Hester refuses. Finally, her husband arrives in the colony and - his marriage to Hester still unrevealed - begins to practise medicine under the assumed name, 'Roger Chillingworth'. Suffering from intense feelings of hypocrisy, Dimmesdale continues in his ministry as his physical health declines but, curiously enough, he seems to wax spiritually and gains increased respect from his Puritan congregation. On more than one occasion this young minister is on the verge of confessing his guilt from the pulpit, but he does not. Chillingworth, then, begins to live with the sickly Dimmesdale to provide medical care and discovers a selfinflicted ' $\mathrm{A}$ ' on his chest, matching the scarlet letter worn by Hester. The vengeful physician engages in mental torture of his wife's seducer. Eventually Dimmesdale publicly proclaims his sin from the local scaffold and reveals his thoracic inscription before collapsing in death.

One does not venture far out on a limb of speculation to suggest that in a conventional Christian context, The Scarlet Letter and, particularly, Dimmesdale's predicament, is a study in the power of unresolved guilt when one does not accept God's grace and forgiveness with the relief from the burden of sin. Balmforth, however, interpreted it differently, at least in the first instance. To him, The Scarlet Letter was a parable illustrating the 'Law of Retribution'. Having no commitment to a belief in an afterlife with reward or punishment, Balmforth denigrated believers who thought that 'God reserves his penalties and his punishments until some far-off day of Judgment'. To this Unitarian, it seemed self-evident that 'Every day is a day of Judgment'. Quoting Hawthorne's contemporary, Ralph Waldo Emerson, he suggested that 'Retribution is swift as the lightning'. Furthermore, Balmforth entreated his flock, 'The faintest speck of rottenness, invisible at first, in the apple or the pear spreads rapidly' according to a universal spiritual law, and 'the laws of the spirit work here and now, universally, unhasting but unresting. No secret sin can escape them' (Balmforth 1912:55-56).

In what might have seemed an anomaly, given the enormous gulf separating much of Balmforth's post-Protestant theology from Roman Catholicism, he then drew explicitly on Dante's Divine comedy, more specifically the second part called Purgatorio, to reveal his appreciation of the orthodox belief that sinners must pass through three stages, namely confession of sin, contrition and satisfaction before entering the gate of Justification. Balmforth acknowledged the great difficulty many people have in confessing their sins, but implored his audience to be honest with themselves and make the effort (Balmforth 1912:59-60). In the end, however, his commitment to progressive modernism won the day as he allowed for the possibility that the 'customs and ideals of one age', seemingly 'harsh and cruel', might be 'succeeded by truer and purer ideals of right' (Balmforth 1912:161). 


\section{Endorsing theological liberalism in Robert Elsmere}

After exploring moral and spiritual principles in several British, continental European and American novels, Balmforth explicitly endorsed religious liberalism or the 'New Theology' in his discourse about Mrs. Humphry Ward's Robert Elsmere. This work of 1888 had quickly become widely popular in England during the years of his metamorphosis from agnostic to Unitarian and may have played some part in it, though there is no direct evidence of such a role. At any rate, Ward's novel encapsulated the struggle to retain Christian faith in an age of scientism, rampant secularism, theological shifts and other challenges. 'Beliefs, especially religious beliefs, are changing rapidly,' Balmforth reminded his congregation, 'and thoughtful people everywhere are asking the searching questions What is the truth? ...' (Balmforth 1912:161)

He described the eponymous hero's spiritual journey as an Oxford graduate and husband of an ardent evangelical who begins his ministerial career as an Anglican divine in Surrey, but is introduced by a scholarly sceptic with whom he interacts frequently to 'critical and historical treatises which are shaking the foundations of current thought'. Among these challenges are Darwinian evolution, theories about the non-Mosaic origins of the Pentateuch (the first five books of the Old Testament), diverse notions about how the gospels in the New Testament came about and are textually related to each other, 'the growth of tradition and legend in the early church', and 'the myths of the miraculous Incarnation and Resurrection' (Balmforth 1912:167). It is a microcosm of 19th-century theological and intellectual currents which had already eroded much public confidence in conventional theology.

Elsmere wrestles almost endlessly with these matters, especially the foundational questions of Biblical infallibility and the identity and significance of Jesus Christ as an incarnation of the divine. He concludes that he believes in Jesus as a 'teacher', a 'martyr', and 'the symbol to us Westerns of all things heavenly and abiding, the image and pledge of the invisible life of the Spirit' (Balmforth 1912:161). But his belief in 'the man-God, the Word from Eternity, in a wonderworking Christ, in a risen and ascended Jesus, in the living Intercessor and Mediator for the lives of his doomed brethren' (Balmforth 1912:168-169) has perished, having fallen victim to modern scholarship.

As a Unitarian, though one whose spiritual journey had arrived at a similar destination after proceeding from a much different point of departure, Balmforth could assure his congregation that Elsmere's radical change of mind was not loss but gain. Unable to continue conscientiously in the established church, the young vicar demits his ministry and launches a new one, emphasising social work in London's East End as a de facto Unitarian.

Balmforth drew three lessons from the symbolic case of Elsmere. The first was that 'character is of more importance than creed'. Accordingly, people should be given an 'absolute right of personal conscientious judgment'. 'The old cry 'Unbelief is $\sin ^{\prime}$ must pass into oblivion,' he (Balmforth 1912:181) told his congregation in Cape Town. Secondly, individual rationalism must be the supreme canon for judging the value of one's faith or religion. 'The only authority is the authority of the human soul, out of which come bibles, creeds, and churches', declared Balmforth. Blind devotion to theological orthodoxy was no longer acceptable. 'Biblical marvels, childish philosophies of the universe, ecclesiastical rites and forms, puerile conceptions of God and heaven, and narrow ideals of human duty' must give way to 'the simple but strenuous religion of Jesus' (Balmforth 1912:184). Finally, and above all else, Balmforth professed that, however obsolete certain particular 'forms of religion' had become, religion as such was still vital. The 'great underlying and over-arching forces which guide, and guard, and inspire our life - God, Nature, Spirit, Destiny' continued intact; indeed, to this parson they were becoming even 'more mysterious and more wonderful' as modern thought was liberating them from 'the superstitions and the miracle-worship of the past' (Balmforth 1912:185).

\section{Conclusion}

Our analysis of a necessarily small but representative sample of Balmforth's preaching about themes or 'laws' in novels yields lessons which remain applicable to homiletics and theology today. Perhaps most obviously, he demonstrated the feasibility of crafting entire sermons about themes in novels and making either only very brief or no reference to the Bible. Nevertheless, despite all his talk about 'deeper insight', greater courage, 'abundant life' and other fruits that can be harvested from careful reading of what he termed 'the best literature', Balmforth's discourses reveal pitfalls which can await us. Who determines what 'the best literature' is? Large numbers of novels foreground and even glorify forms of conduct which ran counter to what he believed was beneficial to humanity. Furthermore, in the wake of the First World War a wave of literary modernism swept across much English and other literature, calling into question the validity of conventional values. Balmforth's stated criteria for assaying the quality of literature no doubt found resonance among other theological liberals. However, one can hardly ignore the fact that in his own day and, subsequently, despite his conviction that post-orthodoxy would necessarily replace the straitjacket which he believed many conventional Christian doctrines such as the atoning death and resurrection of Jesus Christ represented, large numbers of Christians continued to find their spiritual succor in the Bible and the proclamation of its teachings which Balmforth thought had become passé. One can hardly imagine the kind of discourses he read from his pulpit in Hout Street, finding general acceptance in the congregations of theologically conservative churches who longed for and demanded more Biblical meat on the bones.

No doubt to the regret of many retrospective churchmen, his comments about literature, being a potentially more effective means of communication than Biblical or other conventional 
forms of preaching, may well be true in many instances. Of course, diverse factors can qualify this generalisation, such as the seriousness and mental agility of readers, on the one hand, or the homiletical skills of individual preachers on the other. It is conceivable that Balmforth's perennial exploration of novelistic and dramatic works in which these texts did not merely yield illustrations of Biblical themes but themselves served as the written vehicles of moral and ethical principles may well have made an impact on his hearers, confirming in them various principles which had long been the standard fare of this minister's preaching. At any rate, it seems plausible that his preaching about novels received a sufficiently heartening response to prompt him to repeat that form of homiletics mutatis mutandis in his exploration of other genres. That said, one must wonder how effective it would be in proclaiming religious and ethical doctrines to congregations less erudite than his own.

\section{Acknowledgments \\ Competing interest}

The author declares that he has no financial or personal relationships which may have inappropriately influenced him in writing this article.

\section{References}

Balmforth, R., 1898, The evolution of Christianity, Swan Sonnenschein \& Co., Ltd., London.

Balmforth, R., 1904, The Bible from the standpoint of the higher criticism: The Old Testament, Swan Sonnenschein \& Co. Ltd., London.

Balmforth, R., 1905, The New Testament in the light of the higher criticism, Swan Sonnenschein \& Co. Ltd., London.

Balmforth, R., 1911, 'The influence of the Darwinian theory on ethics, with special reference to the ethical conditions of the struggle for existence', South African Journal of Science 7, 386-396.
Balmforth, R., 1912, The ethical and religious value of the novel, George Allen \& Co., Ltd., London.

Balmforth, R., 1913, Drama, music-drama and Religion: As illustrated by Wagner's 'Ring of the Nibelung' and 'Parsifal', The Year Book Press, London.

Balmforth, R., 1925, The ethical and religious value of the drama, George Allen \& Unwin Ltd., London.

Balmforth, R., 1928, The problem-play and its influence on modern thought and life George Allen \& Unwin Ltd., London.

Balmforth, R., 1932, 'Liberal religion as reconciling East and West: Towards a league of religions', The Inquirer 4688(7 May), 234-235.

Balmforth, R., 1911, 'The Influence of the Darwinian Theory on Ethics, with Special Reference to the Ethical Conditions of the Struggle for Existence', South African Journal of Science 7, 386-396.

Balmforth, R., 1935, Jesus - The Man, The C.W. Daniel Company Ltd., London.

Barbour, R., 2000, J.S. Stewart in a nutshell, The Handsel Press, Edinburgh.

Berman, D., 1990, A history of atheism in Britain: From Hobbes to Russell, Routledge, London.

Cope, J., 1942, 'Intrepid Liberal', The Forum 4 (41), 5-6.

Donnelly, S. 2012, email, 17 September, Document@Ise.ac.uk

Farnell, L.R., 1929, 'Comparative religion: Pali, and the religions of India', in C.H. Herford (ed.), Joseph Estlin Carpenter: A memorial volume, pp. 162-178, Clarendon Press, Oxford.

Hale, F., 2007, 'The origins of the Free Protestant Church in South Africa: David P. Faure contra Dutch Reformed Calvinism', Studia Historiae Ecclesiasticae 23 (1), 327-350.

Hyde, M.G., 1963, 'A case study approach to the rhetorical analysis of the Washington preaching of Dr. Peter Marshall', PhD thesis, Michigan State University.

Lischer, R., 1997, The preacher king: Martin Luther King Jr. and the Word that moved America, Oxford University Press, New York. https://doi.org/10.1093/acprof:oso/ 9780195111323.001.0001

Niblett, B., 2011, Dare to stand alone: The story of Charles Bradlaugh, Kramedart Press, Oxford.

Phillips, W.P., 1924, 'Our Cape Town church', The Inquirer 4280(12 July), 461

Royle, E., 1980, Radicals, secularists and republicans: Popular freethought in Britain, 1866-1915, Manchester University Press, Manchester.

Royle, E., 1974, Victorian infidels: The origins of the British Secularist Movement, 1791-1866, Manchester University Press, Manchester.

Ryan, H.R., 1989, Harry Emerson Fosdick, persuasive preacher, Greenwood Press, Inc., Portsmouth, New Hampshire.

Sherwood, T.H., 2010, The preaching of Archbishop Fulton J. Sheen: The gospel meets the Gold War, Lexington Books, Lanham Maryland. 